\title{
ijurr
}

\section{Beyond the Enclave of Urban Theory}

\begin{tabular}{|c|c|}
\hline Journal: & International Journal of Urban and Regional Research \\
\hline Manuscript ID & IJURR-DE-0164.R1 \\
\hline Manuscript Type: & Interventions Essay \\
\hline $\begin{array}{l}\text { Please choose one or two } \\
\text { subject categories that best } \\
\text { describe the article's concerns: }\end{array}$ & $\begin{array}{l}2 \text { Urban movements, social movements, urban politics, citizenship, } \\
\text { underclass \& social exclusion (political aspects), } 6 \text { Urban planning, } \\
\text { transport, security, infrastructure }\end{array}$ \\
\hline Keywords: & $\begin{array}{l}\text { Urban theory, Global urbanism, Stuart Hall, Colombia, Race, Cities, } \\
\text { Urbanization }\end{array}$ \\
\hline $\begin{array}{l}\text { Which world region(s) does the } \\
\text { article focus on? Select up to } \\
\text { five.: }\end{array}$ & $\begin{array}{l}\text { South/Central America \& Caribbean < World Region, Global South }<\text { World } \\
\text { Region, International < World Region, Non-place specific < World Region }\end{array}$ \\
\hline $\begin{array}{l}\text { Which country/countries does } \\
\text { the paper focus on? Select up } \\
\text { to five.: }\end{array}$ & Colombia < South/Central America \& Caribbean < Countries \\
\hline $\begin{array}{r}\text { Which city/cities does the } \\
\text { article focus on? List up to five } \\
\text { cities.: }\end{array}$ & Buenaventura \\
\hline
\end{tabular}




\section{Beyond the Enclave of Urban Theory}

"What I find hard to handle is theory. I find theory exasperating. And I find a confident theory even more exasperating."

-Derek Walcott (2003)

The field of urban studies is presently preoccupied with intense theoretical self-reflection. A question on the minds of many urbanists is how to reformulate our conceptual repertoire in order to theorize the contemporary urban world. The nature of urbanization is under scrutiny as is the scale on which to approach it. As a result, phrases like "global urbanism," "planetary urbanization," "worlding cities," and "a world of cities" are heard regularly. To a certain degree, this scaling up is neither new nor exclusive to urban studies. Since the 1990s, urbanists (along with other social scientists) have been preoccupied with globalization and transnationalism. However, recent attention to the scale of the global and the planetary has followed on the heels of profound challenges to the ontological and epistemological foundations of earlier scholarship.

On the one hand, postcolonial critiques of the geo-politics of knowledge have made evident the need to displace the Euro-American locus of urban theory and to advance more cosmopolitan perspectives on contemporary urban life in its multiple and varied forms. On the other hand, challenges posed to the field's underlying spatial assumptions have led to attempts to theorize urbanization as an extended, "planetary" process that transcends the boundaries of any one particular city. These arguments, which l'll collapse together under the heading "global urban theory," push us, in different ways (some complementary, some contradictory), toward a more worldly urban studies. ${ }^{1}$ This achievement is praiseworthy and long overdue, especially in light of recent attempts to reassert theoretical frameworks derived from urban experiences in the global North. Postcolonial theorists have been the most vocal critics of such resurgent universalisms (Robinson and Roy, 2016; Roy, 2016a), whereas the idea of "planetary urbanization" exhibits its own universalizing tendencies (Oswin, 2016; Peake, 2016; Jazeel, 2017). However, despite important differences, these recent debates have been overly confined to a theoretical register. In contrast, I 
propose an alternative, inspired by Stuart Hall, which focuses attention on the work accomplished by our key concepts beyond the enclave of urban theory. I use "enclave" here in a metaphorical sense to provoke urbanists to think about the boundaries we construct between ourselves and the worlds we seek to understand. My hope is that our critical view of enclaves and the walls erected around them can be used to stimulate an analogously self-critical perspective on our own theorizing practices.

In what follows, I make this argument with reference to my own research in Colombia, focusing specifically on the port-city of Buenaventura. ${ }^{2}$ I discuss why global urban theory is important for understanding urban transformations there, especially their entanglement with relentless patterns of racialized violence and dispossession. I then show how different actors in Buenaventura themselves mobilize the concepts of "global" and "urban" in the service of competing political projects. I conclude by commenting on how we might enrich our understanding of contemporary urban worlds by: 1) embedding our key concepts within what Hall called "historically specific social formations"; and 2) by paying close attention to the social lives of these concepts in the domain of urban politics. ${ }^{3}$ This domain, which consists of the sites and situations in which the urban becomes political (and vice versa), is a central focus of contemporary urban studies (Rodgers, S. et al., 2014). My argument, though not specifically addressed to our understanding of "urban politics," builds on that tradition by approaching the "urban" as a hotly contested category.

Hall's work is generative for urban studies, and indeed has already proved useful for the analysis of the politics of crisis, policing, racial capitalism, multiculturalism, and neoliberalism, among other topics (Gilmore, 2002; Keith, 2009; Elliott-Cooper et al., 2014; Ruggiero, 2014; Peck, 2016; Valayden, 2016). My aim here is not to draw further attention to the generous theoretical repertoire Hall's work offers to urban studies but rather to ask how his method might suggest a reorientation of our field's own theorizing practices. I call this a "method" rather than a "theory" since it does not promise explanations, but rather provides a model for how others might go about their intellectual work. Especially 
instructive is Hall's analyses of "race," for they present us with a way of engaging questions of global urbanism without necessarily treating them as purely theoretical questions.

In his pioneering 1980 essay, "Race, Articulation and Societies Structured in Dominance," Hall turns his attention to apartheid South Africa. He begins by discussing the opposition between "economic" and "sociological" explanations for the apartheid social order-the former prioritizing capitalism, the latter foregrounding racism. Characterizing this opposition as reductive, Hall develops an analytic for understanding capitalism and racism in articulation (Clarke, 2015). "Articulation," in Hall's analysis, is the process by which multiple modes of production are joined together within an historically specific social formation, within which race functions as an "articulating principle." As Sharad Chari (2015) notes, Hall refuses the impulse to understand race in abstraction from other social relations, such as class, while also resisting the urge to reduce the former to the latter. Instead, Hall (1980, p. 338) centers his analysis on the work accomplished by the concept of "race," in particular the discriminatory practices authorized by it: "One must start, then, from the concrete historical 'work' which racism accomplishes under specific historical conditions-as a set of economic, political and ideological practices, of a distinctive kind, concretely articulated with other practices in a social formation." These practices, underpinned by the "articulating principle" of race, ultimately work to "secure the hegemony of a dominant group over a series of subordinate ones, in such a way as to dominate the whole social formation" toward economically productive ends (ibid.).

Another landmark text, "New Ethnicities," published in 1989, further demonstrates Hall's method of analytically embedding key concepts within historically specific social formations rather than removing them to a theoretical register. Here Hall turns to black cultural politics in post-war Britain: specifically the shift from struggles over "relations of representation," which problematized the representation of black identity in cultural and aesthetic discourse, to a "politics of representation," whereby the very nature of black identity itself was called into question. This shift brought renewed interest in the concept of 
"ethnicity," which foregrounded "the place of history, language and culture in the construction of subjectivity and identity," in opposition to the fixed biological essentialism of "race" (Hall, 1996, p. 447). Yet Hall was well aware of the pitfalls of exchanging one concept for the other: "I am familiar with all the dangers of 'ethnicity' as a concept and have written myself about the fact that ethnicity, in the form of a culturally constructed sense of Englishness and a particularly closed, exclusive and regressive form of English national identity, is one of the core characteristics of British racism today" (ibid.). The concept of "race" was necessary for grappling with the opportunities and limits presented by the concept of "ethnicity," but Hall refused to extract either from the social formations in which they were embedded-namely, Thatcherite neoliberalism and multiculturalism. Both concepts were inextricably bound up with contestations over the interlocking questions of how to theorize, legislate, and live with difference.

Hall's engagement with "race" is a model for how we, as urbanists, might approach our own concepts (cf. Alexander 2009). Before proceeding to develop this point with reference to urban transformations in the Colombian port-city of Buenaventura, two qualifications are in order. The first pertains to an apparent paradox: that I am calling for a certain kind of analysis without fully delivering it myself. As a short intervention into theoretical debates, this contribution is meant primarily as a programmatic methodological statement. Though illustrated by empirical material, it is not a full-length research article that offers a model to imitated. Instead, my goal is to inspire others to pursue empirically grounded, contextually specific, fieldwork-based engagements with global urbanism and to provide methodological tools that can be useful for such a pursuit.

The second qualification is that I am by no means proposing an antitheoretical posture for urban studies, nor do I believe such a thing is desirable or even possible. I fully agree with postcolonial urban theorists who urge us to confront the inequalities reproduced by a narrow definition of "what counts as urban theory, who gets to claim such theory and on what grounds" (Robinson and Roy, 2016, p. 5). My own work is deeply indebted to such interventions, 
which have transformed the conceptual repertoire of urban studies, thus enlivening and pluralizing the field's theoretical imagination. However, alongside efforts to democratize the privilege of thinking and speaking in the language of "theory," I propose that Hall's method offers a way to expose that privilege to more fundamental questioning. Resisting the label of "theorist" and making it clear that he was "not interested in the production of theory in its own right" (Grossberg, 2010, p. 27), Hall was nevertheless deeply committed to the intellectual and political stakes of theory. But his commitment was grounded in the awareness of the fact that theory is always already part of the world, entangled with and inseparable from contestations over the meaning of key concepts and the work they accomplish within historically specific social formations. Indeed, Hall embodied a theorizing practice that was "always connected to the specifics of a concrete moment" (Grossberg, 2010, p. 27). In calling urban theory an enclave and seeking to move beyond it, my aim is to use Hall's theorizing practice around "race" to prompt us to deepen our appreciation for the productivity and performativity of our concepts out in the world.

\section{Invisible Cities and Global Urbanism}

In this section, I will elaborate on the points made thus far with reference to my own research in Colombia, focusing specifically on the port-city of Buenaventura and on why global urban theory-in both postcolonial and planetary incarnations-is important for understanding urban transformations there. Colombian cities in general have long been associated with images of urban dystopia (Gutiérrez Sanín et al., 2012). Although this association persists, international observers have begun to lavish praise on charismatic mayors, budding architects, and their creative interventions (Maclean, 2015; Berney, 2017). Colombia is now celebrated as a laboratory of enlightened urban innovation, and this reputation dominates discussions about its cities on an international stage (Montero, 2017). Many stories that do not fit this narrative never surface; others are dismissed as exceptions to an uplifting tale of 
nationwide urban regeneration. These inconvenient truths are mostly found outside the metropolitan centers, or on their peripheries, out of sight. The realities of daily life in small- and medium-sized cities like Turbo, Tumaco, Barrancabermeja, and Montería remain invisible to most urbanists outside Colombia, but also to many working within the country. Though the majority of Colombia's roughly 30 million urbanites live in these cities, and this is where future urban growth is likely to take place, they remain off most maps of the contemporary urban world (Samad et al., 2012).

The port-city of Buenaventura is a prime example. Known colloquially as "el Puerto," Buenaventura now moves a greater volume of merchandise than anywhere else in Colombia, and yet it rarely figures in conversations about Colombian cities (de la Hoz, 2008). Even those who have heard of it sometimes doubt that it even deserves to be called a "city" and are surprised to learn that as many as 350,000 people live there. Though the port of Buenaventura's star is rising, the city of Buenaventura remains relatively invisible. This invisibility is strategic: there are powerful people whose commercial interests-drugs bound for North America, electronics arriving from Asia-depend on keeping it that way. As the amount of trade passing through Buenaventura has risen dramatically in recent years, so have the instances of violence, displacement, and dispossession suffered by residents of the city's waterfront territories (Human Rights Watch, 2014). And despite its increasing economic importance, the city is by far the poorest and least developed in the country (30\% unemployment rate, $80 \%$ of its inhabitants live below the poverty line, and life expectancy there is 11 years less than the national average) (Nicholls and Sánchez-Garzoli, 2011, p. 4). Highlighting the links between global economies, both licit and illicit, and the persistent humanitarian crisis there threatens to expose the brutality underpinning business as usual.

This brief sketch of Buenaventura's position within discourses about cities, both within and beyond Colombia, suggests there are good reasons to draw on insights from various strands of global urban theory. Ever since its foundation by Spanish explorers in 1540, and especially after the Panama Canal opened in 
1914, Buenaventura has been, first and foremost, a port-an aperture through which people, goods, and wealth could pass on their way to elsewhere (Suárez Reyes, 2010 , p. 2491). Thinking about the urban from a port-city automatically suggests extraterritoriality, translocality, even globality. But the recent project of turning Buenaventura into a "world-class port-city" makes it all the more appropriate to analyze ostensibly local transformations in relation to global processes of capitalist urbanization. Following this line of thinking, rapid social and spatial changes in and around Buenaventura are clearly linked to the ascendance of the Chinese economy and its expanding reach throughout Latin America, the transoceanic shipping industry and transnational investments in maritime infrastructure, and hemispheric networks of drug trafficking and the paramilitary violence that sustains them (Business Monitor International, 2014). Urban transformations in specific sites, such as along Colombia's Pacific coast, are no doubt entangled with and shaped by wider circuits of capital accumulation (Brenner, 2013).

The case of Buenaventura also resonates with efforts to chart new geographies of urban theory, for it shifts attention away from the metropolitan centers-whether in Europe, North America, or elsewhere in the global Souththat dominate urban studies (Roy, 2014). In doing so, it expands the range of locations that contribute to contemporary theoretical debates. This has important conceptual implications, such as the suggestion that the field of urban studies needs to pay more attention to the racialized politics of precarity under late liberalism (Ranganathan, 2016), particularly in coastal cities where waterfront settlements are vulnerable to multiple forms of insecurity. As I have argued elsewhere, we need new concepts for apprehending the forms of urban political life specific to the territorial conflicts underway in Buenaventura, as well as those unfolding under similar circumstances in other parts of the world [reference removed for review]. Using cities like Buenaventura as places from which to generate (rather than merely apply) urban theory is indeed a necessary step on the path to a more cosmopolitan urban studies. 
These related approaches to theorizing contemporary urban worlds also have important political implications. Connecting transformations in Buenaventura to processes of capitalist urbanization implicates the rest of Colombia as well as other parts of the world, such as China, Dubai, Spain, Mexico, and the United States, in an urban crisis that is too often circumscribed locally. Likewise, placing Buenaventura within a world of cities counteracts the strategic ignorance that enables the violent reality of everyday life there to remain invisible. For these and other reasons, Buenaventura demands the sort of conceptual imagination enabled by recent work in global urban theory.

However, this recent work raises key questions about the "urban" and its relationship to the "global" at the same time that it tends to confine these concepts to the enclave of urban theory. ${ }^{5}$ To illustrate an alternative approach, I'll discuss, first, how different actors in Buenaventura themselves mobilize visions of the "global" in service of competing political projects and, second, how the "urban" is a hotly contested concept with serious consequences for lives and livelihoods. Inspired by Hall's method, and in particular his attention to "articulating principles of social formations," I will attend to the discursive and material work these concepts perform within a specific historical conjuncture. I'll then conclude by arguing that more attention should be paid to how our concepts move beyond the enclave of urban theory and proceed to do things in the world.

\section{Competing Global Visions}

In Buenaventura, competing visions of the "global" are at the heart of increasingly volatile and violent processes of urban transformation. This is highlighted by the conflict between official plans to turn the city into Colombia's primary commercial port and alternative proposals from activists and residents from areas slated for urban and infrastructural development. These opposing political projects differ markedly in how they envision the relationship between the city and the world. With reference to Hall's analytical vocabulary, we might say 
that the "global" has become an articulating principle of dominant social formations in the port-city, as well as of oppositions to them.

The national and local governments both imagine Buenaventura becoming a "world-class port-city" (Ministerio de Trabajo, 2012). As Colombia's only Pacific Ocean port, enthusiasm for Buenaventura's rapidly rising "good fortune" is tied to projections of booming trade relations with Asia (Business Monitor International, 2014). With commentators far and wide heralding the advent of the "Chinese (or Asian) century," Buenaventura has been labeled "Colombia's gateway to the Pacific" (Schipani, 2014a), which the local development plan calls the "basin of the future" (Ministerio de Trabajo, 2012). Lucrative transoceanic fantasies also inspire the burgeoning Pacific Alliance, which seeks greater economic integration and reduced tariff barriers between Colombia, Mexico, Chile, and Peru and since 2013 boasts Buenaventura as its capital (Schipani, 2014b). Meanwhile, a free trade agreement with Colombia's largest trading partner, the United States, which went into effect in 2012, promises a $\$ 1.1$ billion expansion of imports, many of which would be destined for Buenaventura (Nicholls and Sánchez-Garzoli, 2011). These global visions-however utopian-are producing material effects. Vast amounts of public and private capital, from the Colombian government and investors from Europe, Asia, North America, and the Middle East, are being funneled into infrastructure megaprojects to accommodate, but also to entice, the anticipated increase of goods passing through the port in years to come (EI Tiempo, 2012). Enabling these transformations is the articulating principle of the "global," which links together economic, political, and ideological practices into a dominant vision of the future.

Standing in the way of these plans are waterfront settlements collectively known as Bajamar (meaning "low-tide") built and inhabited primarily by AfroColombians. These settlements are occupied by an estimated 110,000 inhabitants, approximately one third of the city's total population. Positioned at the intertidal zone between land and sea, in recent years they have become subject to mounting displacement pressures. In spite of these pressures, activists and residents of Bajamar question the Colombian state's vision of the global 
economic future and the central role Buenaventura is expected to play in it. They argue that the certainty with which the national and local governments foresee the "Pacific century" is not matched by observers elsewhere, pointing to cautious (even pessimistic) assessments from the likes of the World Bank and the Chinese government's own economic advisory body (The World Bank and The Development Research Center of the State Council, 2013). Despite such warnings, the Colombian state remains confident that increasing economic ties with China, and ramping up the capacity of its Pacific seaport, are the keys to strengthening the country's global competitiveness and securing future prosperity.

In the popular imagination, Colombia's coastal populations have long been associated with Africa (Wade, 2002). Seen from the country's highland interior, this association is the basis for a host of racialized stereotypes of the darkerskinned inhabitants of the Caribbean and Pacific coasts (Leal, 2008). Likewise, the coastal regions, especially the Pacific, are seen as the "Africa of Colombia," indexing levels of poverty and underdevelopment far above the rest of the county (Wade, 2002; Barbary and Urrea, 2004). In recent decades, however, AfroColombian social movements have affirmed their own place within the African diaspora, yet to different effect (Cárdenas, 2010). They articulate the structural position of the Afro-descendent population within Colombian society in relation to historical patterns of discrimination and dispossession throughout the Americas (Unión Portuaria, 2014). In Buenaventura, activists connect the lucrative transPacific fantasies of the "world-class port-city" to the trans-Atlantic networks of exchange that brought Afro-descendent populations to the Colombian Pacific in the first place (Castro, 2017). This vision of the "global" connects histories of racialized violence and transoceanic trade linking disparate ports, coastlines, and seas between Africa, Europe, and the Americas (Gilroy, 2007). Racial slavery, plantation agriculture, and gold mining in the past, much like drug trafficking, infrastructure development, and globalized commerce in the present, are predicated on the dehumanization of African diasporic life (Barragan, 2017; Alves, 2017). 
The Afro-Colombian geographical imagination is partly expressed in musical terms, from traditional styles like marimba and currulao to more recent inventions such as reggae, hip-hop, and reggaetón (Birenbaum Quintero, 2013). Through music, but also by way of more explicitly political forms of communication, social movements have begun to connect to a diasporic politics of global struggle that stretches from Brazil to South Africa to Jamaica to the United States (Branche, 2015; Lao-Montes, 2016; Vergara Figueroa and Arboleda Hurtado, 2016). This makes Buenaventura a node in global networks of racial justice activism, which is reflected in the conflict between official plans for the port-city's future and alternative scenarios proposed by Afro-Colombian groups. The latter oppose port expansion to the extent that it perpetuates a longstanding historical pattern whereby the development of the interior and the wealth accumulated by light-skinned Colombians are predicated on the exploitation and underdevelopment of black populations along the coasts (Escobar, 2004). If plans to increase economic ties with China and turn Buenaventura into a "worldclass port-city" could upset that pattern, they might support them. But since history and experience suggest otherwise, the political and cultural mobilizations that oppose port expansion express that opposition through a diasporic vision of Buenaventura's place in the modern/colonial world (Quijano, 2007). Again the "global" serves as an articulating principle of an historically specific social formation, but for different political ends.

\section{The Politics of Urbanity}

I'll now move to discuss the concrete consequences of how the "urban" is conceptually defined, legally codified, governmentally managed, politically contested, and socially lived. The vast majority of Buenaventura's 350,000 inhabitants are of African descent, and the city has long been a hub of AfroColombian politics and activism. This means that efforts to resist violence, displacement, and dispossession are conditioned by the history of ethno-racial politics in Colombia and, in particular, by how black populations are positioned, 
and position themselves, as legal and political subjects (Paschel, 2016). Since the adoption of a new constitution in 1991, the Colombian state has recognized itself officially as "multicultural" and "pluri-ethnic." The subsequent passage of Law 70, or the Law of Black Communities, in 1993, granted Afro-Colombians a range of symbolic and material rights. Crucially, Law 70 granted these rights to comunidades negras ("black communities") officially defined as a culturally distinct ethnic group with collective title to rural lands (Restrepo, 2004). This codification constituted the black political subject in particular ways-what Roosbelinda Cárdenas (2012), following Hall, calls the "articulation of black multiculturalism." This articulation continues to shape territorial struggles underway in Buenaventura.

The Process of Black Communities (or PCN for short) is one of the primary organizations advocating for Afro-Colombian rights. PCN is better characterized as an activist network than a single group, and its influence extends throughout the black communities of the Pacific coast (Escobar, 2008). Many of these communities live in resource-rich areas frequently under attack by paramilitary groups allied with agribusiness, mining, or energy companies (Asher, 2009; Leal, 2013). However, as territorial dispossession in rural areas continues to push Afro-Colombian communities into cities like Buenaventura (Oslender, 2007), and as forced displacement increasingly unfolds within cities, PCN (2011) is struggling with the question of what black political subjectivity means in an urban context. Here we have an historical conjuncture in which the "urban" comes to do consequential political work. Following Hall's method, we can see it as an articulating principle that structures the social formation within which AfroColombians struggle to defend their lives and livelihoods.

Popular assumptions about race and space further complicate matters. Afro-Colombians living in the predominantly white and mestizo cities of the interior are presumed to be "displaced" (both in the official sense of belonging to the internally displaced population and in the more general sense of not being where they "belong," that is on the Caribbean or Pacific coasts) (Arboleda, 2004). These assumptions compromise the ability of Afro-Colombians throughout the 
country to be recognized as urban citizens in both a symbolic and material sense (Agudelo, 2004; Observatorio Contra la Discriminación y el Racismo, 2012). But while those living in Bogotá and Medellín are understood as "out of place" on account of residing in the interior rather than on the coasts (Wade, 1993), in Buenaventura this is due to their presence in urban settlements rather than in rural areas. As a result, activists increasingly see the need to establish AfroColombian rights in (and to) the city and to reconfigure the legal and political geography that limits their agency in an urban context.

The displacement pressures mounting in Buenaventura principally affect territories that have been occupied by Afro-descendent populations for over 50 years in some cases, which have more recently become politically and economically strategic (CODHES and SJR, 2013). PCN activists call these comunidades afro-urbanas (“Afro-urban communities”). This particular combination of ethno-racial and spatial classifications intentionally disrupts the politically and legally binding association of the black population with rural land. Although it explicitly marks a difference between urban and rural AfroColombians, their collective rights regardless of location are at stake here.

PCN activists argue that the systematic clearance of land required for urban and infrastructural development in Buenaventura, whether done legally by the municipal government or illegally by paramilitary groups, violates their right to consulta previa (prior consultation) (Bocarejo, 2014). This is the formal mechanism that entitles black communities to participate in decisions regarding development projects that affect them. But juridically speaking there is no rights infringement since prior consultation applies only to "black communities" as defined by law - that is, those with collective title to rural lands-rather than to the Afro-Colombian population as a whole. The same is true for the Victims and Land Restitution Law, passed in 2011, which mandates the restoration of property to rural communities who had been forced by the armed conflict to abandon it. These entitlements subsume Afro-Colombians in the city within the generic urban population, rendering them unintelligible as differently positioned political 
subjects - a hard-won status that emerged from years of struggle to document unequal exposure to racialized violence and marginalization (Paschel, 2010).

It is becoming increasingly clear that the articulating principle of the "urban" (and, conversely, the "rural"), once codified in legislation and policy, segments Afro-descendent populations and limits their collective rights. "We see much of Buenaventura as an extension of el campo poblado (the settled countryside)," a PCN leader told me, "that has come about in the same way that black communities have been occupying and inhabiting territory throughout history." Settlement patterns are not the only thing that defies the rural/urban divide along the Pacific Coast. Forced displacement, which has disproportionately affected Afro-Colombians, ensures that stable, long-term relationships between people and place are untenable (Oslender, 2007). That said, moving to urban areas rarely means abandoning established cultural practices, social relations, or sources of livelihood, and many Afro-Colombians in cities maintain dynamic connections with their communities of origin (Oslender, 2016).

Nevertheless, Afro-Colombian social movements know that intersecting ethno-racial and spatial classifications both enable and constrain their efforts to resist violence, displacement, and dispossession. Activists are well aware that these classifications fundamentally shape the rights they have, the protections they are entitled to, and the demands they can make on the state. This momentarily aligns them with strains of global urban theory that recognize the political (or ideological) implications of narrowly circumscribed definitions of the "urban." Yet there are two important differences: while urbanists would tend to ratchet up this insight to the level of theory, activists would likely find such attempts inconsequential relative to their political struggles; and while the former would be inclined to push toward a definitive or coherent conceptualization of the "urban," the latter would likely adopt a more flexible position on its ontological and epistemological status. After all, as Hall might put it, the political implications of any one articulation of the "urban" depend on the specific historical conjuncture and social formation in which it takes shape. 


\section{Beyond the Enclave of Urban Theory}

Recent work in urban theory hinges on the question of whether we can agree upon a "coherent concept of the city as an object of theoretical inquiry" (Scott and Storper, 2015, p. 10). This quote comes from a recent article by Allen Scott and Michael Storper, and yet the question is shared by Neil Brenner and Christian Schmid's writings on "planetary urbanization" (Brenner, 2013; Brenner and Schmid, 2015). Scott and Storper's answer is "yes" while Brenner and Schmid say "no," with the latter pushing for the concept of "urbanization" instead of the "city." Yet these authors all seem to agree that this question is the question demanding a response. I would also venture to say that the same question animates recent articles from postcolonial urbanists (Roy, 2009; Robinson and Roy, 2016) as well as work on assemblage urbanism (Farías and Bender, 2010; McFarlane, 2011; Blok and Farías, 2016). Conceptual coherence is less important here, and yet the primary concern is still how to reformulate our theoretical repertoire in order to better understand the contemporary urban world.

While this emerging body of work poses fundamental questions about the definition of the "urban" and its relationship to the "global," I worry about the consequences of confining both concepts to the enclave of urban theory. Similarly, if we currently have "a plurality of different concepts of the urban," as Scott and Storper (2014:10) note, global urban theory seems to offer two responses: assert that one concept is more fundamental, more coherent, more universal than all the others; or justify conceptual plurality on the grounds that contemporary urbanization is too variegated to be captured by any single concept or theory (Leitner and Sheppard, 2016). I myself am partial to the second response, but I worry that, like the first, it again draws our attention back to the "urban" as a theoretical question. As Robinson and Roy (2016, p. 4) note, the tug of war between ambitious universalism and conceptual multiplicity creates a theoretical impasse. One way to loosen this deadlock is to examine the social lives of our key concepts beyond the enclave of urban theory. 
My goal in this essay has been to present Stuart Hall's analysis of race, articulation, and social formations as a model for urban studies. For Hall's method allows us to see the "urban" and "global" as at once theoretical questions, practical questions, political questions, economic questions, legal questions, aesthetic questions, and moral questions, none of which is reducible to any other and all of which fundamentally shape social life. This cannot be explained or even appreciated if global urbanism is discussed on a purely theoretical register. While the ontological and epistemological status of these categories is important, I find it equally so to examine the practical and political work they do in the world. Like "race" in Hall's analysis, concepts like the "urban" are never only theoretical considerations, but "articulating principles" of social formations, producing both discursive and material effects, and possessing social, cultural, and political lives of their own.

This leads me to wonder why urbanists get nervous when the "urban" becomes too polymorphous or slips out of our hands. ${ }^{6}$ Perhaps we are concerned about losing control over our central organizing concept, hence the recent flurry of papers attempting to systematize, clarify, or redefine it. For the sake of comparison, I want to offer a reflection from the discipline of anthropology. Beginning in the 1980s, anthropology faced a disciplinary crisis in some ways analogous to the current moment in urban studies. Many anthropologists found it deeply unsettling that people around the world were realizing that "culture" was not something they unknowingly "had" or "did," but something that they themselves had an interest in defining and shaping (and not just as a set of practices or a way of life but also as a category or concept).

Anthropologists were accustomed to having the first and last word on the subject. Indeed, some within the discipline reacted by reasserting themselves as arbiters of cultural identity, tradition, and authenticity. This allowed them to acknowledge that "culture" was in some ways beyond their control while still preserving the integrity and authority of their existing conceptual frameworks. Other anthropologists, some of them directly influenced by Stuart Hall, allowed this phenomena to radically transform their field. ${ }^{7}$ They accepted that the 
theoretical question of defining (and defending) the "culture" concept was perhaps less important than the ways in which the concept was being defined (and defended) far beyond the pages of their academic journals. These anthropologists relinquished their professional claims to conceptual ownership and got on with the task of understanding how "culture" was being constituted and contested out in the world (Trouillot, 2003).

It may be time that urbanists did something similar by recognizing that our concepts and theories do not belong exclusively to us. How we go about theorizing global urbanism matters, and should be debated; but our debates are not separate from a world in which people everywhere are asking and answering both global and urban questions. The tide of global urban theory may be rising, and for good reason. But it must not be allowed to drown empirically grounded scholarship that pays close attention to the social lives of concepts like the "urban" and the "global" and the work they do in the world. After all, beyond the enclave of urban theory, the stakes of defining the terms of global urbanism are highest.

In closing, I want to pose a question for future consideration: Can Hall's work make an even more substantive intervention into urban studies than the methodological one presented thus far? Implicit in the empirical material from Colombia I have discussed is the fact that the articulating principles of the "urban" and "global" intersect directly with "race," and that all three are inextricable bound. This suggests that it is not only Hall's method that is indispensable for the study of urban transformations. Indeed, one could go further to argue that Hall's analysis of "racially-structured social formations" can also be extended to the domain of global urbanism. Although beyond the scope of this essay, we may want to consider the degree to which "race" operates as an articulating principle, together with the "urban" and the "global," to structure the social formations underpinning contemporary capitalist urbanization. AbdouMaliq Simone's (2016a) provocation to think urbanity and blackness together is already moving the field of urban studies in this direction. ${ }^{8}$ Departing from a concern for how people both survive and strive alongside urbanization processes throughout the world, 
Simone's notion of "blackness as urban method" calls "for a creative reconstruction of accounts of collective black life as a means to get a different angle on city life and urban theorization" (2016b, p. 212). If we take this provocation seriously, Simone argues, we can no longer "rest at ease with the theories of the city being put into play today" (2016b, p. 217). Hall's work similarly suggests that urbanists grapple more forcefully with "race," but that in doing so we recognize ourselves and our conceptual debates as always already part of the world.

\section{References}

Agudelo, C. E. (2004) No todos vienen del río: construcción de identidades negras urbanas y movilización política en Colombia. In Restrepo, E. and A. Rojas (eds.), Conflicto E (In)visibilidad: Retos En Los Estudios de La Gente Negra En Colombia. Universidad del Cauca, Popayán.

Alexander, C. (2009) Stuart Hall and 'Race'. Cultural Studies 23.4, 457-82.

Alves, J. A. (2017/29/May) Colombia Negra: Abandono, vida civil y furia en la ciudad portuaria de Buenaventura. openDemocracy.

Arboleda, S. (2004) Negándose a ser desplazados: afrocolombianos en Buenaventura. In Restrepo, E. and A. Rojas (eds.), Conflicto $E$ (In)visibilidad: Retos En Los Estudios de La Gente Negra En Colombia. Universidad del Cauca, Popayán.

Asher, K. (2009) Black and Green: Afro-Colombians, Development, and Nature in the Pacific Lowlands. Duke University Press, Durham.

Barbary, O. and Urrea, F. eds. (2004) Gente Negra en Colombia: Dinámicas Sociopolíticas en Cali y el Pacifico. Editorial Lealon, Medellín.

Barnett, C. and Bridge, G. (2016) The Situations of Urban Inquiry: Thinking Problematically about the City. International Journal of Urban and Regional Research 40.6, 1186-1204.

Barragan, Y. (2017) To End 500 Years of Great Terror. NACLA Report on the Americas 49.1, 56-63.

Berney, R. (2017) Learning from Bogotá: Pedagogical Urbanism and the Reshaping of Public Space. University of Texas Press, Austin.

Birenbaum Quintero, M. (2013) De ritos a ritmos: las prácticas musicales afropacíficas en la época de la etnodiversidad. In Restrepo, E. (ed.), Estudios Afrocolombianos Hoy: Aportes a Un Campo Transdiciplinario. Universidad del Cauca, Popayán.

Blok, A. and Farías, I. eds. (2016) Urban Cosmopolitics: Agencements, assemblies, atmospheres. Routledge, Abingdon.

Bocarejo, D. (2014) Legal Typologies and Topologies: The Construction of Indigenous Alterity and Its Spatialization Within the Colombian Constitutional Court. Law \& Social Inquiry 39.2, 334-60. 
Branche, J. C. (2015) The Poetics and Politics of Diaspora: Transatlantic Musings. Routledge, New York.

Brenner, N. (2013) Theses on Urbanization. Public Culture 25.1, 85-114.

Brenner, N. and Schmid, C. (2015) Towards a new epistemology of the urban? City 19.2-3, 151-82.

Business Monitor International (2014) Colombia Shipping Report Q2. London.

Cárdenas, R. (2010) Trayectorias de negridad: disputas sobre las definiciones contingentes de lo negro en América Latina. Tabula Rasa 13, 147-89.

Cárdenas, R. (2012) Multicultural Politics for Afro-Colombians: An Articulation 'Without Guarantees'. In Black Social Movements in Latin America: From Monocultural Mestizaje to Multiculturalism. Palgrave Macmillan, New York.

Castro, N. (2017/5/July) Del Palenque al paro en Buenaventura: la larga lucha de los afrocolombianos. Equal Times.

Chari, S. (2015) Three Moments of Stuart Hall in South Africa: PostcolonialPostsocialist Marxisms of the Future Introduction: Reading Hall from South Africa. Critical Sociology.

Clarke, J. (2015) Stuart Hall and the theory and practice of articulation. Discourse $36.2,275-86$.

Clifford, J. (1988) The Predicament of Culture: Twentieth Century Ethnography, Literature and Art. Harvard University Press, Cambridge.

Clifford, J. (2000) Taking Identity Politics Seriously: 'The Contradictory, Stony Ground'. In Gilroy, P., L. Grossberg and A. McRobbie (eds.), Without Guarantees: In Honour of Stuart Hall. Verso, London.

CODHES and SJR (2013) Buenaventura: una crisis humanitaria que urge respuestas. Bogotá.

de la Hoz, J. V. (2008) Economías del Pacífico colombiano. Cartagena.

Derickson, K. D. (2017) Urban geography II: Urban geography in the Age of Ferguson. Progress in Human Geography 41.2, 230-44.

El Tiempo (2012) Conozca los megaproyectos de Buenaventura. El Tiempo.

Elliott-Cooper, A., du Boulay, E. and Kilroy, E. (2014) Moral panic(s) in the 21st century. City 18.2, 160-66.

Escobar, A. (2004) Desplazamientos, desarrollo y modernidad en el Pacífico colombiano. In Restrepo, E. and A. Rojas (eds.), Conflicto E (In)visibilidad: Retos En Los Estudios de La Gente Negra En Colombia. Universidad del Cauca, Popayán.

Escobar, A. (2008) Territories of Difference: Place, Movements, Life, Redes. Duke University Press, Durham.

Farías, I. and Bender, T. eds. (2010) Urban Assemblages: How Actor-Network Theory Changes Urban Studies. Routledge, New York.

Gilmore, R. W. (2002) Fatal Couplings of Power and Difference: Notes on Racism and Geography. The Professional Geographer 54.1, 15-24.

Gilroy, P. (2007) Offshore Humanism: Human Rights and Hydrarchy. In Trevor, T. (ed.), Port City. Arnolfini, Bristol.

Grossberg, L. (2010) Cultural Studies in the Future Tense. Duke University Press, Durham.

Gutiérrez Sanín, F., Gutiérrez, M. T., Guzmán Pardo, T., Arenas Gómez, J. C. 
and Pinto, M. T. (2012) Of Guns, Ideas, and Taxes: Understanding the Political Logic of Violence-Reducing Policy Innovation in Three Colombian Cities. In Rodgers, D., J. Beall and R. Kanbur (eds.), Latin American Urban Development into the 21st Century. Palgrave Macmillan, London doi:10.1016/B978-0-08-100662-7.00001-4.

Hall, S. (1980) Race, Articulation and Societies Structured in Dominance. In UNESCO (ed.), Sociological Theories: Race and Colonialism. UNESCO, Paris.

Hall, S. (1986) Gramsci's Relevance for the Study of Race and Ethnicity. Journal of Communication Inquiry 10.2, 5-27.

Hall, S. (1996) New Ethnicities. In Morley, D. and K.-H. Chen (eds.), Stuart Hall: Critical Dialogues in Cultural Studies. Routledge, London.

Human Rights Watch (2014) The Crisis in Buenaventura. Washington, D.C. Jazeel, T. (2017) Urban theory with an outside. Environment and Planning D: Society and Space.

Keith, M. (2009) Urbanism and City Spaces in the Work of Stuart Hall. Cultural Studies 23.4, 538-58.

Lao-Montes, A. (2016) Afro-Latin American Feminisms at the Cutting Edge of Emerging Political-Epistemic Movements. Meridians 14.2, 1-24.

Leal, C. (2008) Usos del concepto 'raza' en Colombia. 389-438.

Leal, C. (2013) Freedom in the rainforest: Black peasants and natural resource extraction in Colombia's Pacific coast, 1850-1930. In Abreu, M., C. V. Dantas and H. Mattos (eds.), Histórias Do Pós-Abolição No Mundo Atlântico: Identidades $E$ Projetos Políticos. Editora da Universidade Federal Fluminense, Niterói.

Leitner, H. and Sheppard, E. (2016) Provincializing Critical Urban Theory: Extending the Ecosystem of Possibilities. International Journal of Urban and Regional Research 40.1, 228-35.

Maclean, K. (2015) Social Urbanism and the Politics of Violence. Palgrave Macmillan, Basingstoke.

McFarlane, C. (2011) Assemblage and Critical Urbanism. City 15.2, 204-24.

Ministerio de Trabajo (2012) Buenaventura, ciudad puerto de clase mundial: Plan local de empleo 2011-2015. Buenaventura: Ministerio de Trabajo, Fundación Panamericana para el Desarrollo.

Montero, S. (2017) Study tours and inter-city policy learning: Mobilizing Bogotá's transportation policies in Guadalajara. Environment and Planning A 49.2, 332-50.

Nicholls, K. and Sánchez-Garzoli, G. (2011) Buenaventura, Colombia: Where Free Trade Meets Mass Graves. NACLA Report on the Americas.

Observatorio Contra la Discriminación y el Racismo (2012) Discriminación laboral en Cali: Un acercamiento desde la desigualdad socio-demográfrica en el área metropolitana. Ministerio del Interior, Bogotá.

Oslender, U. (2007) Violence in development: the logic of forced displacement on Colombia's Pacific coast. Development in Practice 17.6, 752-64.

Oslender, U. (2016) The Geographies of Social Movements: Afro-Colombian Mobilization and the Aquatic Space. Duke University Press, Durham. 
Oswin, N. (2016) Planetary urbanization: A view from outside. Environment and Planning D: Society and Space.

Parnell, S. and Pieterse, E. (2016) Translational Global Praxis: Rethinking Methods and Modes of African Urban Research. International Journal of Urban and Regional Research 40.1, 236-46.

Paschel, T. S. (2010) The Right to Difference: Explaining Colombia's Shift from Color-Blindness to the Law of Black Communities. American Journal of Sociology 116.3, 729-69.

Paschel, T. S. (2016) Becoming Black Political Subjects: Movements and EthnoRacial Rights in Colombia and Brazil. Princeton University Press, Princeton.

PCN (2011) Propuesta autónoma de reparación colectiva para comunidades negras de Buenaventura.

Peake, L. (2016) The Twenty-First-Century Quest for Feminism and the Global Urban. International Journal of Urban and Regional Research 40.1, 219-27.

Peck, J. (2016) Transatlantic city, part 1: Conjunctural urbanism. Urban Studies 54.1, 4-30.

Quijano, A. (2007) Coloniality and Modernity/Rationality. Cultural Studies 21.2-3, 168-78.

Ranganathan, M. (2016) Thinking with Flint: Racial Liberalism and the Roots of an American Water Tragedy. Capitalism Nature Socialism 5752.July, 1-17.

Restrepo, E. (2004) Ethnicization of Blackness in Colombia: Toward Deracializing Theoretical and Political Imagination. Cultural Studies 18.5, 698715.

Restrepo, E. and Rojas, A. eds. (2004) Conflicto e (in)visibilidad: Retos en los estudios de la gente negra en Colombia. Universidad del Cauca, Popayán.

Robinson, J. (2002) Global and World Cities: A View from Off the Map. International Journal of Urban and Regional Research 26.3, 531-54.

Robinson, J. and Roy, A. (2016) Global Urbanisms and the Nature of Urban Theory. International Journal of Urban and Regional Research 40.1, 181-86.

Rodgers, S., Barnett, C. and Cochrane, A. (2014) Where is Urban Politics? International Journal of Urban and Regional Research 38.5, 1551-60.

Roy, A. (2009) The 21st-Century Metropolis: New Geographies of Theory. Regional Studies 43.6, 819-30.

Roy, A. (2014) Worlding the South: Towards a Post-Colonial Urban Theory. In Parnell, S. and S. Oldfield (eds.), The Routledge Handbook on Cities of the Global South. Routledge, Abingdon.

Roy, A. (2016a) Who's Afraid of Postcolonial Theory? International Journal of Urban and Regional Research 40.1, 200-209.

Roy, A. (2016b) What is urban about critical urban theory? Urban Geography $37.6,810-23$.

Ruggiero, V. (2014) Policing the Crisis thirty-five years on. City 18.2, 149-51.

Safransky, S. (2014) Greening the urban frontier: Race, property, and resettlement in Detroit. Geoforum 56, 237-48.

Samad, T., Lozano-Gracia, N. and Panman, A. (2012) Colombia Urbanization Review: Amplifying the Gains from the Urban Transition. Washington, D.C.

Schipani, A. (2014a/1/April) Pacific Alliance opens doors for businesses in Latin 
America. Financial Times.

Schipani, A. (2014b/1/April) Lawless Colombia port to play key role in Pacific Alliance. Financial Times.

Scott, A. J. and Storper, M. (2015) The Nature of Cities: The Scope and Limits of Urban Theory. International Journal of Urban and Regional Research 39.1, $1-15$.

Simone, A. (2016a) Urbanity and Generic Blackness. Theory, Culture \& Society 33.7-8, 183-203.

Simone, A. (2016b) It's Just the City after All! International Journal of Urban and Regional Research 40.1, 210-18.

Suárez Reyes, F. (2010) Buenaventura: Una ciudad-puerto, globalizante, diversa y multicultural. In Rey Tristán, E. and P. Calvo González (eds.), 200 Años de Iberoamérica (1810-2010): Congreso Internacional: Actas Del XIV Encuentro de Lationoamericanistas Españoles. Universidade de Santiago de Compostela, Servizo de Publicacións e Intercambio Científico, Santiago de Compostela.

The World Bank and The Development Research Center of the State Council, P. R. C. (2013) China 2030: Building a Modern, Harmonious, and Creative Society. Washington, D.C. doi:10.2139/ssrn.1188022.

Trouillot, M.-R. (2003) Adieu, Culture: A New Duty Arises. In Global Transformations: Anthropology and the Modern World. Palgrave Macmillan, New York.

Unión Portuaria (2014/30/December) Colombian port workers in solidarity against police violence. San Francisco Bay View: National Black Newspaper: 1-6.

Valayden, D. (2016) Racial Feralization: Targeting Race in the Age of 'Planetary Urbanization'. Theory, Culture \& Society 33.7-8, 159-82.

Vergara Figueroa, A. and Arboleda Hurtado, K. (2016) Afrodiasporic Feminist Conspiracy: Motivations and Paths forward from the First International Seminar. Meridians 14.2, 118.

Wachsmuth, D. (2014) City as ideology: reconciling the explosion of the city form with the tenacity of the city concept. Environment and Planning D: Society and Space 32.1, 75-90.

Wade, P. (1993) Blackness and Race Mixture: The Dynamics of Racial Identity in Colombia. Johns Hopkins University Press, Baltimore.

Wade, P. (2002) The Colombian Pacific in Perspective. Journal of Latin American Anthropology 7.2, 2-33.

Walcott, D. (2003) Exasperating Theory. In Enwezor, O., C. Basualdo, U. M. Bauer, S. Ghez, S. Maharaj, M. Nash and O. Zaya (eds.), Créolité and Creolization. Hatje Cantz Publishers, Ostfildern-Ruit.

\section{Notes}

\footnotetext{
${ }^{1}$ My intention is not to conflate diverse approaches to theorizing the urban nor is it to present an evaluative review of these approaches. Instead, my aim is to highlight an implicit assumption shared across a heterodox field of inquiry, which is itself characterized by otherwise significant analytical and political difference.
} 
${ }^{2}$ This article draws primarily on interviews and site visits conducted in 2013 during two short period of fieldwork in Buenaventura. One visit coincided with an event that brought together activists, community leaders, NGOs, municipal authorities, lawyers, urbanists, and members of the interested public to discuss the question of territorios afro-urbanos ("Afro-urban territories"). The argument is based also on interviews conducted with activists, humanitarian workers, and government officials in Bogotá as well analysis of policy and planning documents, media archives, and cultural productions. Though long-term fieldwork in Buenaventura was deemed unfeasible due to the security situation, supporting the analysis is over a decade of research on security and urban politics in Colombia. A fuller engagement with race, space, and urban politics in Buenaventura can be found in [reference removed for review].

${ }^{3}$ My approach is influenced by Stuart Hall's analysis of race as a "social formation," his concept of "articulation," and his historical-conjunctural method. In Colombia, especially in the Pacific coast region, Hall's work has been influential to scholars of race and ethnicity (Barbary and Urrea, 2004; Restrepo and Rojas, 2004; Cárdenas, 2012; Bocarejo, 2014), and their work has in turn shaped my own perspective. In urban studies, an inspirational reference point is also Jennifer Robinson's (2002) germinal critique of the "global city" concept as a "regulating fiction." Other urbanists have suggested something along the lines of what I am proposing here, though perhaps less explicitly or with other analytical methods. For example, see Parnell and Pieterse's (2016) discussion of a "translational" mode of urban research, Roy's (2016b) attention to the urban as a governmental category, Wachsmuth's (2014) move to consider the city as a "category of practice" with ideological repercussions. For two especially lucid interventions, see Barnett and Bridge's (2016) suggestion to treat urban thought "problematically" and Jazeel's (2017) push to think from "outside" urban theory. While my focus will be on the "global" and the "urban," my argument pertains to all key concepts in urban studies.

${ }^{4}$ Hall's use of the concept of "articulation" draws on Antonio Gramsci and is in dialogue with others in the Marxist tradition, such as Louis Althusser, Ernesto Laclau, and Chantal Mouffe. Urbanists, too, have used this concept to various ends. For example, Ananya Roy, citing Michael Dear and Oren Yiftachel, asks: "What does it mean to think about contemporary urbanism via articulation rather than agglomeration?" (2016a, p. 206). Common across these engagements with the concept is a reaction against universalisms of various kinds. However, Hall stands out for the degree to which he made articulation central to his linked political, pedagogic, and intellectual projects (Clarke, 2015, p. 275) and for his resistance to allow it to become a "theoretical" principle (Hall, 1986). The following remark on Gramsci illuminates Hall's unique perspective: "He was constantly using 'theory' to illuminate concrete historical cases or political questions; or thinking large concepts in terms of their application to concrete and specific situations. Consequently, Gramsci's work often appears almost too concrete: too historically specific, too delimited in its references, too 'descriptively' analytic, too time and context-bound. His most illuminating ideas and formulations are typically of this conjunctural kind" (1986, p. 6).

${ }^{5}$ Clive Barnett and Gary Bridge have identified a similar tendency: "Debates about the future of critical urban theory continue to presume that concepts of urban inquiry remain the special preserve of a cadre of intellectuals, secure from the temptations of ideology and with access to the properly theoretical apprehension of spatial concepts" (2016, p. 16).

${ }^{6}$ As AbdouMaliq Simone notes, this conceptual anxiety parallels long-standing fears of the city as the site of "dangerous circulations of all kinds, from disease, panics, social contagion and crowds" (2016b, p. 213).

For example, see the pioneering work of James Clifford (1988; 2000).

${ }^{8}$ For other particularly generative examples, see Kate Derickson (2017), Sara Safransky (2014), and Malini Ranganathan (2016). 